\title{
Abundance and diversity of tidal marsh plants along the salinity gradient of the San Francisco Estuary: implications for global change ecology
}

\author{
Elizabeth Burke Watson · Roger Byrne
}

Received: 15 April 2007/Accepted: 16 March 2009/Published online: 10 April 2009

(C) The Author(s) 2009. This article is published with open access at Springerlink.com

\begin{abstract}
From 2003 through 2005, tidal marsh plant species diversity and abundance on historically surveyed vegetation transects along the salinity gradient of the San Francisco Estuary were investigated to establish empirical relationships between plant distributions and environmental conditions, and furthermore to examine and predict past and future plant distribution changes. This study suggests that for most species, salinity is the primary control on plant distribution. Thus, ongoing changes in estuarine conditions (increasing sea level and salinity) are resulting in a complex mix of plant distribution changes. On the low marsh, where sediment salinity is similar to that of ambient water, halophytic species are replacing salt-intolerant taxa. However, on marsh plains, where increased tidal flooding is moderating high salinity (concentrated by evaporation), halophytic "high marsh" species are being replaced by
\end{abstract}

Electronic supplementary material The online version of this article (doi:10.1007/s11258-009-9602-7) contains supplementary material, which is available to authorized users.

E. B. Watson · R. Byrne

Geography Department, University of California,

507 McCone Hall, Berkeley, CA 94720, USA

E. B. Watson $(\bowtie)$

Department of Land, Air \& Water Resources,

University of California, Davis, 228 Veihmeyer Hall,

One Shields Ave., Davis, CA 95616, USA

e-mail: elizabeth.b.watson@gmail.com salt-intolerant "low marsh" taxa. Thus, future changes in plant distributions will hinge on whether marsh sediment accumulation keeps pace with sea level rise.

Keywords Climate change .

Environmental conditions - Species diversity .

Vegetation cover $\cdot$ Salinity

\section{Introduction}

Estuarine wetlands are dynamic coastal landforms that provide valuable ecological habitat and services; their productivity is among the highest of any terrestrial or marine system. They act as nurseries for juvenile fish and invertebrates, provide habitat for migrating and resident birds, buffer the coastal zone from erosion and coastal flooding, and act as nutrient transformers in global biogeochemical cycles (Odum 1980; USFWS 1987; Adam 1990; Mitsch and Gosselink 2000). Coastal wetlands are vulnerable to degradation due to the combined effects of accelerated sea level rise and pre-existing stressors created by anthropogenic actions; consequently, the ongoing deterioration of tidal marsh habitat throughout the United States has been well documented (Baumann et al. 1984; Hartig et al. 2002; Van Dyke and Wasson 2005).

Because tidal wetlands are both ecologically valuable and exceptionally vulnerable to the effects of climate change, studies have been undertaken to 
determine the vulnerability of specific tidal wetlands to habitat deterioration. Multi-year studies in a wide variety of ecological settings have reported that many wetlands are not maintaining a positive accretionary balance relative to tidal datums (Day et al. 1999; Culberson et al. 2004; van der Wal and Pye 2004); in some locations, dramatic changes in vegetation over the past decades have been reported and linked to accelerated sea level rise and differential rates of marsh accretion (Orson and Howes 1992; Warren and Niering 1993; Donnelly et al. 1999; Donnelly and Bertness 2001).

The purpose of this study was to predict how tidal marsh vegetation across the full salinity gradient of the San Francisco Estuary will respond to future changes in environmental conditions caused by anthropogenically driven climate change. In the San Francisco Estuary, anthropogenically driven warming is resulting in both an increase in the rate of relative sea level rise (NOAA 2007), and an increase in summer estuarine salinity. Summer salinity is increasing because higher spring temperatures are causing runoff peaks to occur earlier in the year (Knowles and Cayan 2002). The Bay-Delta estuary is transitioning from an estuary in which summer and fall melt waters moderate estuarine salinity to an estuary where intense flow peaks and salinity minimums coincide with rainfall events. With respect to estuarine salinity, this situation is exacerbated by diversion of large volumes of water $\left(\sim 6 \mathrm{~km}^{3}\right.$ annually) for municipal and agricultural purposes (Knowles 2002).

Although tidal wetlands in the San Francisco Estuary are thought to be resilient to sea level rise over the next century as long as sediment supply remains adequate (Orr et al. 2003), it is likely that noticeable changes in vegetation composition and abundance will occur (Callaway et al. 2007). The ultimate goal of this study was to determine whether future changes in environmental conditions in the San Francisco Estuary will most likely lead to subtle or substantial changes in marsh species composition.

To predict future vegetation changes, we first established relationships between modern tidal marsh vegetation and current environmental conditions along the historically surveyed vegetation transects. We then examined vegetation changes that occurred between 1975 and 2003/2004 in light of changes in environmental conditions that occurred over the same period. Finally, we developed potential scenarios for future environmental changes, and used these scenarios to forecast future wetland vegetation changes.

The specific objectives of this study were to: (1) establish empirical relationships between tidal marsh vegetation and environmental conditions, (2) to examine past and predict future changes in vegetation based on ongoing changes in estuarine conditions.

\section{Methods}

Study area

The San Francisco Estuary is the largest estuary on the west coast of the United States (Conomos et al. 1985). It receives drainage from a watershed that encompasses more than $40 \%$ of California (SFEP 2008), and supports the largest area of tidal wetlands in California (Conomos 1979; Grewell et al. 2007). Near the Golden Gate, surface water in the bay is similar in salinity to ocean water; however, salinity falls with distance from the Golden Gate and drops to $<2 \%$ in the Sacramento-San Joaquin Delta (Uncles and Peterson 1995). Because California experiences a Mediterranean climate with cool, wet winters and dry, hot, windy summers (Pyke 1972), estuarine salinity is usually at its maximum during August or September, and at its minimum during the peak of snowmelt runoff, which varies yearly with snowpack and spring temperature (Conomos 1979; Peterson et al. 1995).

Survey stations were established along six tidal marsh transects located across the full salinity gradient of the San Francisco Estuary (Fig. 1; see supplementary material). These transects were originally established and surveyed by USGS scientists in the 1970s (Atwater and Hedel 1976) due to concerns about the effects of future water diversions on tidal marsh ecology. These transects were established specifically to inventory baseline conditions so that future change could be detected. More specifically, these sites were chosen because these locations (1) contained areas of "natural" (i.e., Late Holocene) tidal marsh, (2) spanned the full salinity gradient of the estuary, (3) had experienced minimal hydrologic modifications, and no known subsidence due to groundwater or natural gas pumping, and (4) contained extensive mudflat-to-upland transitions to ensure the representation of all the habitat types. 
Fig. 1 Location map of San Francisco Estuary tidal marsh research sites showing average surface salinity (Sources: Uncles and Peterson 1996; Knowles 2000)

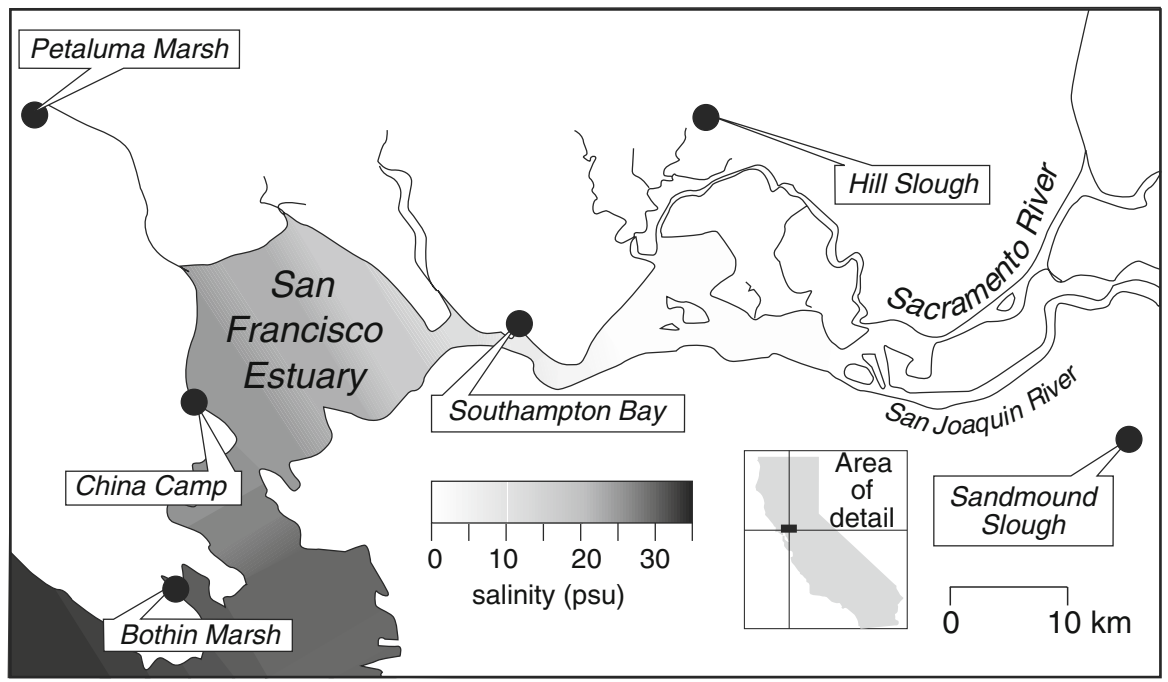

Atwater and Hedel (1976) described the vegetation of these marshes approximately three decades ago. Typically, the low marsh was dominated by Spartina foliosa where ambient water salinity was greater than 15\%, and by Scirpus californicus, Phragmites australis, or Typha sp. where ambient salinity was lower than $15 \%$. In the salt marshes-estuarine wetlands west of Carquinez Strait - the marsh plain largely supported pickleweed, Salicornia virginica, except adjacent to mudflats, tidal channels or upland areas, where species less tolerant of saline conditions and/or anoxia could persist. Consequently, species diversity in salt marshes was found to be typically quite low ( $\sim 10$ species). In brackish marshes, species richness was higher, and a more evenly distributed mixture of species was found growing on the marsh plain, including Scirpus maritimus, Scirpus americanus, Jaumea carnosa, Juncus sp., Distichlis spicata, and other species typical of salt and freshwater marshes (e.g., Limonium californicum, Frankenia salina, Salicornia virginica, Typha sp., etc.). However, anecdotal reports have suggested that up-estuary expansions of halophytic species might have occurred in the time since this survey was conducted in the 1970s.

Objective 1: marsh vegetation and current environmental conditions

In order to adequately establish relationships between tidal marsh plant species and environmental conditions, the historically surveyed transects were re-located and re-surveyed for both tidal marsh plant presence and abundance and environmental conditions (elevation, sediment salinity, and distance to the nearest tidal channel.)

Along each transect, survey stations were established and positioned between 1 and $4 \mathrm{~m}$ apart. Each station was occupied formally once during summer 2003 or 2004; with an additional occupation during 2005 to informally assess vegetation fidelity. Plant cover was assessed, elevation measured, and distance to the nearest channel of greater than one meter was recorded. At two locations, the initial transects covered less than $100 \mathrm{~m}$. At these sites (Bothin Marsh and Sandmound Slough), additional parallel transects were run to increase the number of survey stations. Plant cover was estimated visually in a circle of $1-\mathrm{m}$ radius, with results summing to $100 \%$. Plant species' nomenclature follows that of Hickman (1993). Plant voucher specimens from each marsh were collected and deposited in the herbarium of the University of California (UC) Berkeley Museum of Paleontology Pollen Laboratory.

Elevations along vegetation transects were measured using a TopCon Total Station GS-4 and were calculated relative to National Geodetic Vertical Datum (NGVD) through referencing transects to Coast and Geodetic Survey benchmarks (see supplementary material). Accuracy was estimated for survey data by doing back shots to a stationary target at approximately every five stations. Data were discarded and generally re-shot for errors greater than 1 to $2 \mathrm{~cm}$. The NGVD datum was chosen, as most benchmarks were 
originally surveyed relative to NGVD; referencing marsh transects to tidal datums was not generally possible, as very few tidal benchmarks located nearby marshes were surveyed relative to NAVD or NGVD. Mudflat topography surveys were done by canoe or kayak using a stadia rod at high tide.

For each survey station, the near-surface marsh sediments were also sampled by taking $10-\mathrm{cm}$ soil cores once during the summer months of July through September of 2003 and 2004 (avoiding spring tides), which were both normal rainfall years in Central California. Sediments were integrated over the top $5 \mathrm{~cm}$, and analyzed for organic content and sediment salinity. Organic content was determined by ashing for $4 \mathrm{~h}$ at $550^{\circ} \mathrm{C}$. Sediment salinity was assessed primarily using the dilution method (USSL 1954), although 80 samples were subjected to both the dilution and saturation extract methods (Bower and Wilcox 1965). We found the saturation extract method to be poorly reproducible and to dampen the variability present in salinity measurements. Sediment salinity was calculated by re-hydrating dried, ground sediment samples in a 5:1 gravimetric mixture of distilled water to sediment, stirring, allowing equilibration over $48 \mathrm{~h}$, and measuring the salinity of the mixture using a YSI 10/30 conductivity, temperature, and salinity meter. Pore water salinity was then calculated based on the original water content of the sediment sample. Some mid- and high-marsh sediments contained, gravimetrically, more salts than water; therefore, a few measurements are over $1000 \%$, and many measurements showed a salinity greater than that of seawater.

Surveyed transects were anchored with GPS measurements (and in some cases landscape features) and plotted on USGS Digital Ortho Quarter Quadrangles (DOQQs) using ArcGIS version 9.1. Distance to the nearest channel was assessed for each survey station by measuring the distance from the survey station to the centerline of the nearest tidal channel (of greater than $2 \mathrm{~m}$ in width) on site imagery.

In order to determine whether plant distributions were related to environmental conditions, species ranges along environmental gradients were determined, and in addition, linear and logistic regressions were used in order to determine which environmental variables predicted species presence and abundance. Using salinity, distance to the nearest tidal channel, and elevation as predictors, logistic regression was used to determine the extent to which individual predictors explained presence and absence of marsh species. In order to determine the degree to which differences in percent cover of individual species were explained by environmental conditions, multivariate linear regression was used, with plant cover for individual plant species as the dependent variable, and elevation, summer sediment salinity, distance to the nearest tidal channel, and sediment organic content as the predictor variables.

In addition to species autecology, specific attention was paid to plant species diversity over the salinity gradient of the estuary. In order to determine whether there was a relationship between salinity and diversity, tabulates of plant species richness (median number of species per station and median number of species per $30 \mathrm{~m}$ ) and evenness (Simpson's diversity index and number of species with greater than $2 \%$ total cover) at both the plot and landscape were produced and related to environmental conditions.

In order to approximate the annual salinity range of ambient water flooding each marsh, water salinity was measured during extreme high-water events during late summer (27 August 2004) and winter directly following an intense storm (11 January 2005). As ambient water salinity can vary by several practical salinity units (psu) over the course of a tidal cycle, the tide waves were followed by car. At each location, from five to ten surface-salinity measurements were made using a YSI 10/30 m.

Objective 2: past and future changes in vegetation

The consideration of past and future changes in environment conditions with respect to San Francisco Estuary tidal marshes was restricted to changes in estuarine salinity and water level changes (and related factors). Although other changes (such as form and concentration of dissolved nutrients, grazing stress, and adjacent land use change) are also occurring, such shifts vary from site to site, and are not regularly monitored. Furthermore, nutrient addition was found to produce no measurable effects in the competitive advantage for specific species or for species diversity in other Central Californian marshes (Traut 2003, 2005), and therefore, the results of such changes are probably subtle.

Changes in plant species abundance between 1975 and 2003/4 were reconstructed by finding the 
difference between the 1975 presence/absence data and the 2003/2004 presence/absence data for each species at each site. If the median of these values was found to be significantly different from 0 (using the sign test), a significant change was noted. Further detail of the resurvey is reported by Watson (2006). For each site, plant distribution (for common marsh plants) was mapped along the environmental conditions of salinity and elevation. Shifts in plant abundance (1975 vs. 2003/2004) were examined in light of environmental gradients found at each marsh site and changes in environmental conditions (i.e., increasing salinity and increasing rates of sea level rise).

Because current tidal marshes support such a diverse array of environmental conditions, future predictions for each site were made based on current marsh analogs. In order to predict changes resulting from increasing estuarine salinity, it was assumed that overall marsh species composition would begin to resemble the more saline marsh stations. In order to predict changes resulting from increasing water levels, it was assumed that overall marsh species composition would begin to resemble lower elevation stations.

\section{Results}

\section{Plant distributions}

Environmental conditions appeared to determine both the presence and absence of specific tidal marsh plants at survey stations, and to explain differences in percent cover between stations. First, the presence and absence of common marsh species corresponded with environmental gradients along surveyed transects (Fig. 2). Second, logistic regression showed significant relationships between environmental conditions and the presence and absence of common marsh species (Table 1). Third, plant species distributions were found to correspond with specific environmental ranges (Fig. 3). Finally, environmental conditions appeared to explain a significant component of variability in percent cover for most common tidal marsh species (Table 2).

In the more saline marshes (Southampton Bay, Petaluma Marsh, China Camp, and Bothin Marsh), the dominant plant species, Salicornia virginica was
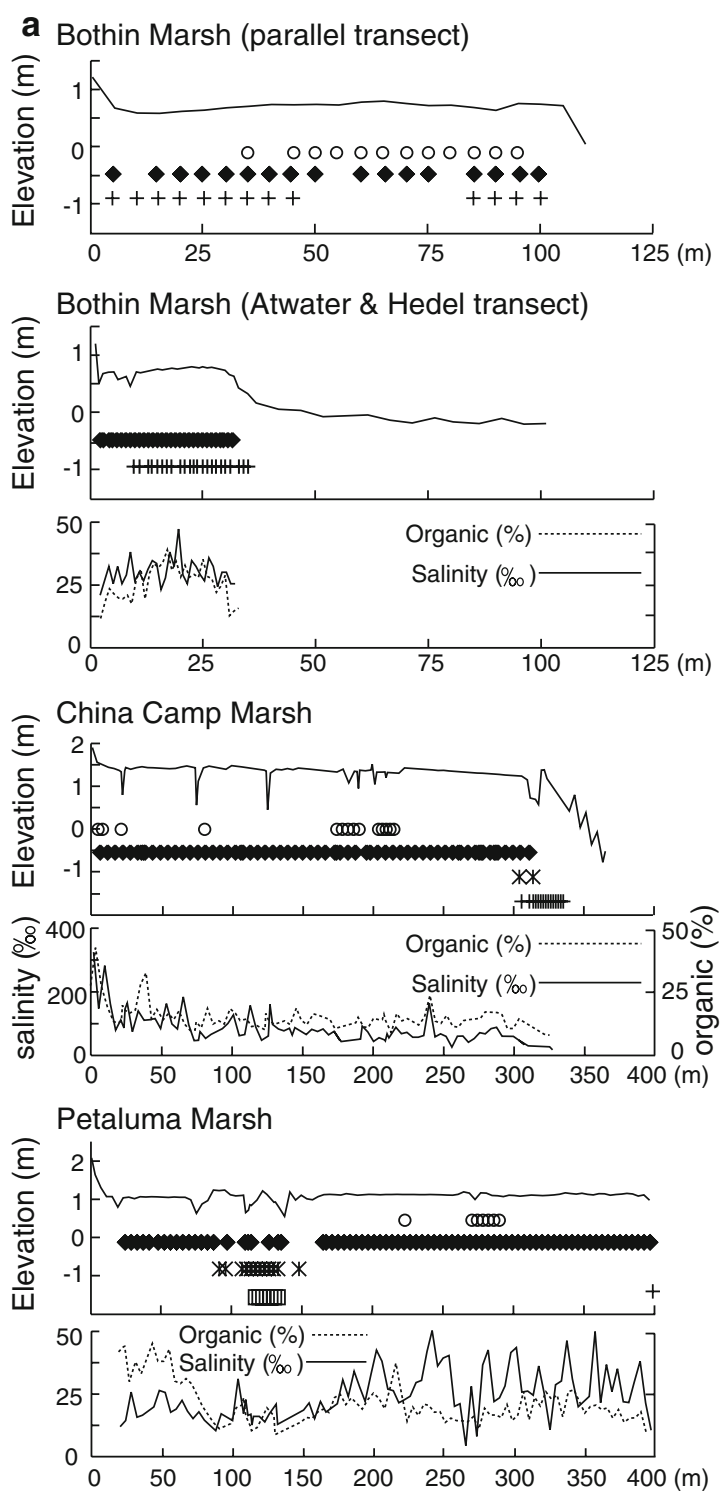

- Distichlis spicata + Spartina foliosa $\downarrow$ Salicornia virginica * Scirpus maritimus $\square$ Scirpus americanus

Fig. 2 a Elevation and edaphic characteristics of tidal marsh vegetation transects re-occupied during the summers of 2003 and 2004 at Bothin Marsh, China Camp Marsh, and Petaluma Marsh. At Bothin Marsh, the top transect is the northernmost transect. b Southampton Bay, Hill Slough, and Sandmound Slough. At Sandmound Slough, the top transect is the northernmost transect

pervasive; other species were generally only found adjacent to tidal channels or to the shoreline, where sediment salinity was lower (Fig. 2). Environmental conditions were found to explain the presence and absence of common tidal marsh species using logistic 

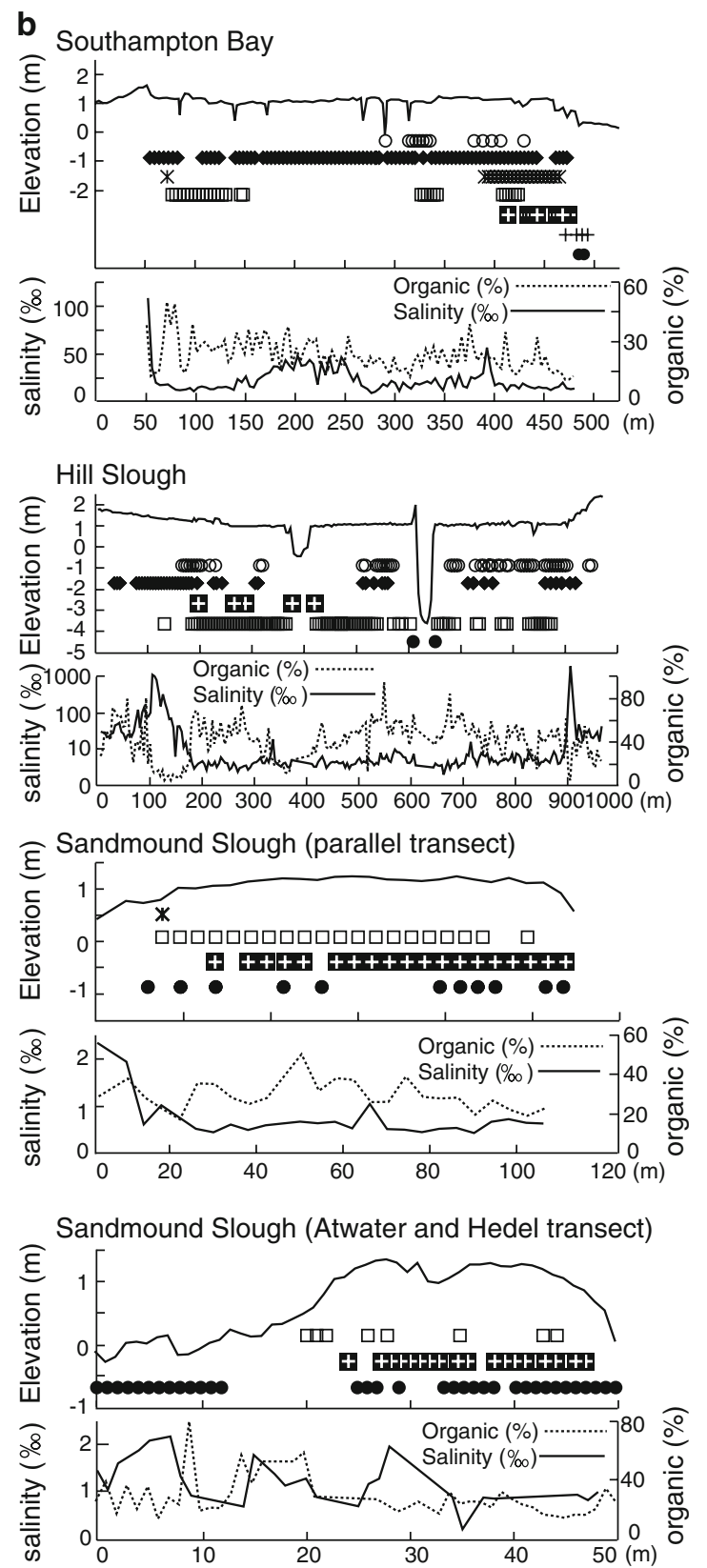

- Distichlis spicata + Spartina foliosa - Salicornia virginica * Scirpus maritimus $\mathbf{+}$ Typhasp. $\quad \square$ Scirpus americanus - Scirpus californicus

Fig. 2 continued

regression (Table 1). Based on probability values, the relationship between environmental conditions and species presence or absence appeared strongest with salinity, but the relationship was also strong for elevation (in the case of Distichlis spicata), and for distance to the nearest tidal channel (in the case of Spartina foliosa). In order to allow for a rough comparison of odds-ratios (the odds of a species being present or absent given an increase in the predictor by one unit), elevation values were converted from meters NGVD to centimeters NGVD.

Species varied in their distribution along environmental gradients (shown by Figs. 2, 3). For example, the sites, where Salicornia virginica was found, on average, had sediments with salinities 13-90 times greater, were $0.8 \mathrm{~m}$ higher in elevation, and were $20.1 \mathrm{~m}$ further from tidal channels than the sites where Scirpus californicus was found. Among the common tidal marsh plants, Salicornia virginica was found to be the most salt-tolerant, often growing in sediments with pore-water salinities many times greater than sea water (inter-quartile range $(\mathrm{IQR})=17.2-57.2 \%$ ). Spartina foliosa was found rooted in sediments with salinities similar to that of sea water (IQR = 22.5-33.1\%o), while Scirpus americanus, Scirpus californicus, and Typha sp. were found growing in sediments with salinities significantly lower than that of sea water (IQRs $=1.8$ $5.9 \%$ o, 0.64-1.3\%o, and 0.56-3.3\%o, respectively).

Although many studies have linked marsh zonation with topographic gradients, this study found substantial overlap in the elevational ranges of common marsh plants (Fig. 3). Scirpus californicus was unique in being rooted below local mean sea level, and was observed to be partially submerged even during the lowest tides of the year. Scirpus californicus also was observed growing at high elevations, often on natural or degraded artificial levels bordering tidal channels. Typha sp. and Spartina foliosa were usually found at lower elevations than Scirpus americanus, Scirpus maritimus, Salicornia virginica, and Distichlis spicata. Among common tidal marsh plants, Typha sp., Scirpus californicus, and Spartina foliosa were found adjacent to channels, while Scirpus americanus, Scirpus maritimus, Salicornia virginica, and Distichlis spicata were found both adjacent to and distant from tidal channels. Environmental conditions appear to explain a significant component of variability in percent cover in all species (Table 2); however, these relationships vary over the salinity gradient of the estuary, as species are found under slightly different conditions at different sites. 
Table 1 Logistic regression results. Species presence is the dependent variable; environmental conditions are the independent variables

\begin{tabular}{|c|c|c|c|c|}
\hline & & $\begin{array}{l}\text { Distance to nearest } \\
\text { tidal channel }(\mathrm{m})\end{array}$ & Elevation $(\mathrm{cm})$ & $\begin{array}{l}\text { Summer sediment } \\
\text { salinity (psu) }\end{array}$ \\
\hline \multirow[t]{2}{*}{ Distichlis spicata } & Odds ratio & 1.01 & 1.01 & 0.997 \\
\hline & $P>\mathrm{OR}$ & 0.206 & 0.043 & 0.251 \\
\hline \multirow[t]{2}{*}{ Salicornia virginica } & Odds ratio & 1.01 & 1.01 & 1.05 \\
\hline & $P>\mathrm{OR}$ & 0.002 & $<0.001$ & $<0.001$ \\
\hline \multirow[t]{2}{*}{ Scirpus americanus } & Odds ratio & 1.00 & 1.00 & 0.877 \\
\hline & $P>\mathrm{OR}$ & $>0.5$ & $>0.5$ & $<0.001$ \\
\hline \multirow[t]{2}{*}{ Scirpus californicus } & Odds ratio & 0.912 & 0.995 & 0.419 \\
\hline & $P>\mathrm{OR}$ & $<0.001$ & 0.006 & $<0.001$ \\
\hline \multirow[t]{2}{*}{ Scirpus maritimus } & Odds ratio & 0.993 & 1.00 & 0.985 \\
\hline & $P>\mathrm{OR}$ & 0.328 & $>0.50$ & 0.017 \\
\hline \multirow[t]{2}{*}{ Spartina foliosa } & Odds ratio & 0.906 & 0.995 & 0.997 \\
\hline & $P>\mathrm{OR}$ & $<0.001$ & 0.003 & 0.468 \\
\hline \multirow[t]{2}{*}{ Typha sp. } & Odds ratio & 0.934 & 1.00 & 0.958 \\
\hline & $P>\mathrm{OR}$ & 0.001 & 0.489 & 0.002 \\
\hline
\end{tabular}

The presence and absence of all the species is best explained by salinity, except for Distichlis spicata, which is best explained by elevation, and Spartina foliosa, whose distribution is best explained by distance to nearest tidal channel. In order to compare oddsratios (the odds of species being present or absent given a unit increase of the predictor), elevation values were converted from meters NGVD to cm NGVD. For species with odds-ratios of less than one, the probably of species presence drops as the predictor variable increases. For species with odds-ratios greater than one, the probably of species presence increases as the predictor variable increases

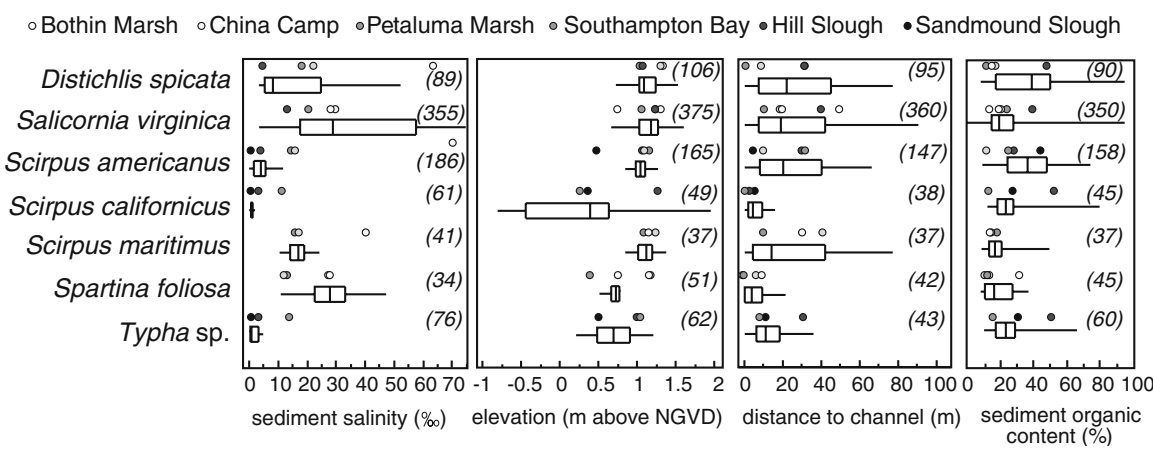

Fig. 3 Elevation, channel distance, summer soil porewater salinity ranges, and sediment organic content boxplots (interquartile range shown, median divides the box) for common

Intra-site comparisons

At extreme high water, surface water salinity at these sites ranged from $0.3 \%$ to $32.5 \%$ (Table 3 ). Summer maximum salinities declined linearly with distance from the Pacific Ocean, indicating well-mixed surface waters. There was more variability in the winter salinities, indicative of local creeks freshening surface waters following rainfall. Along the Petaluma tidal marsh plant species. Numbers in parentheses indicate sample size. Medians for individual marshes are shown by the shaded circles

River and at Coyote Creek, a small creek draining the eastern flank of Mt. Tamalpais at Bothin Marsh, surface waters were fresher during winter than might otherwise be expected based on position along the salinity gradient of the estuary.

At the three most saline marshes, only four to six plant species had greater than $2 \%$ cover along the transects (see supplementary material). Overall, Salicornia virginica was the most common species, 
Table 2 Multiple regression results

\begin{tabular}{|c|c|c|c|c|c|c|c|c|}
\hline & & $\begin{array}{l}\text { Bothin } \\
\text { Marsh }\end{array}$ & $\begin{array}{l}\text { China } \\
\text { Camp }\end{array}$ & $\begin{array}{l}\text { Petaluma } \\
\text { Marsh }\end{array}$ & $\begin{array}{l}\text { Southampton } \\
\text { Bay }\end{array}$ & $\begin{array}{l}\text { Hill } \\
\text { Slough }\end{array}$ & $\begin{array}{l}\text { Sandmound } \\
\text { Slough }\end{array}$ & Overall \\
\hline \multirow[t]{3}{*}{ Distichlis spicata } & $r^{2}$ & - & 0.57 & 0.55 & 0.63 & 0.12 & - & 0.25 \\
\hline & $P>F$ & - & 0.15 & 0.70 & 0.068 & 0.14 & - & $<0.001$ \\
\hline & $n$ & - & 12 & 7 & 12 & 56 & - & 88 \\
\hline \multirow[t]{3}{*}{ Salicornia virginica } & $r^{2}$ & 0.58 & 0.072 & 0.29 & 0.20 & 0.74 & - & 0.12 \\
\hline & $P>F$ & $<0.001$ & 0.20 & $<0.001$ & $<0.001$ & $<0.001$ & - & $<0.001$ \\
\hline & $n$ & 31 & 84 & 81 & 89 & 62 & - & 347 \\
\hline \multirow[t]{3}{*}{ Scirpus americanus } & $r^{2}$ & - & - & 0.94 & 0.51 & 0.16 & 1 & 0.12 \\
\hline & $P>F$ & - & - & 0.11 & $<0.001$ & 0.0025 & $<0.001$ & 0.002 \\
\hline & $n$ & - & - & 7 & 29 & 97 & 6 & 349 \\
\hline \multirow[t]{3}{*}{ Scirpus californicus } & $r^{2}$ & - & - & - & - & - & 0.68 & 0.51 \\
\hline & $P>F$ & - & - & - & - & - & $<0.001$ & $<0.001$ \\
\hline & $n$ & - & - & - & - & - & 28 & 30 \\
\hline \multirow[t]{3}{*}{ Scirpus maritimus } & $r^{2}$ & - & - & 0.79 & 0.34 & - & - & 0.27 \\
\hline & $P>F$ & - & - & 0.0087 & 0.13 & - & - & 0.0371 \\
\hline & $n$ & - & - & 13 & 21 & - & - & 37 \\
\hline \multirow[t]{3}{*}{ Spartina foliosa } & $r^{2}$ & 0.74 & 0.60 & - & - & - & - & 0.31 \\
\hline & $P>F$ & $<0.001$ & 0.82 & - & - & - & - & 0.17 \\
\hline & $n$ & 21 & 6 & - & - & - & - & 29 \\
\hline \multirow[t]{3}{*}{ Typha sp. } & $r^{2}$ & - & - & - & 0.69 & 0.86 & 0.67 & 0.59 \\
\hline & $P>F$ & - & - & - & 0.02 & 0.12 & 0.016 & $<0.001$ \\
\hline & $n$ & - & - & - & 14 & 8 & 15 & 37 \\
\hline
\end{tabular}

Plant cover is the dependent variable; environmental conditions (sediment salinity, sediment organic content, elevation, and distance to the nearest tidal channel) are the independent variables. Probability of a greater $F$ ratio is shown by the notation $P>F$

Table 3 Seasonal differences in surface water salinity at study sites at extreme high water $( \pm \mathrm{SD})$

\begin{tabular}{lcc}
\hline & Summer & Winter \\
\hline Bothin Marsh & $33 \pm 3.2$ & $3.2 \pm 0.89$ \\
China Camp & $27 \pm 11$ & $11 \pm 1.1$ \\
Petaluma Marsh & $25 \pm 2.3$ & $2.3 \pm 0.69$ \\
Southampton Bay & $15 \pm 4.8$ & $4.7 \pm 1.7$ \\
Hill Slough & $5.5 \pm 0.95$ & $0.95 \pm 0.39$ \\
Sandmound Slough & $0.6 \pm 0.3$ & $0.3 \pm 0.1$ \\
\hline
\end{tabular}

followed by Distichlis spicata, and Spartina foliosa. Among the three brackish marshes, nine to twelve species had greater than $2 \%$ cover along transects. Common species in all the marshes surveyed included Scirpus americanus, Salicornia virginica, Typha sp., Potentilla anserina, and Scirpus californicus. Among the four brackish marshes, Lepidium latifolium, a noxious invader of riparian and brackish areas throughout the west (Chen et al. 2005; Young et al. 1995), was among the most common species.

Tidal marsh plant species richness and evenness varied over the salinity gradient of the estuary (Fig. 4). Species richness at the plot and landscape scale was low at the three most saline sites (Bothin Marsh, China Camp, and Petaluma Marsh), and was the highest at the lowest-salinity sites. Measures of species evenness were the highest at Southampton Bay, Hill Slough, and Sandmound Slough, and was the lowest at China Camp and Petaluma Marsh.

Past and future changes in plant distribution

Survey transects were chosen for study because they had been surveyed previously for plant cover and elevation in 1975. Intra-site comparisons show significant species declines along the fresh and brackish marsh transects since 1975, and species expansions along the salt marsh transects (Watson 2006). 

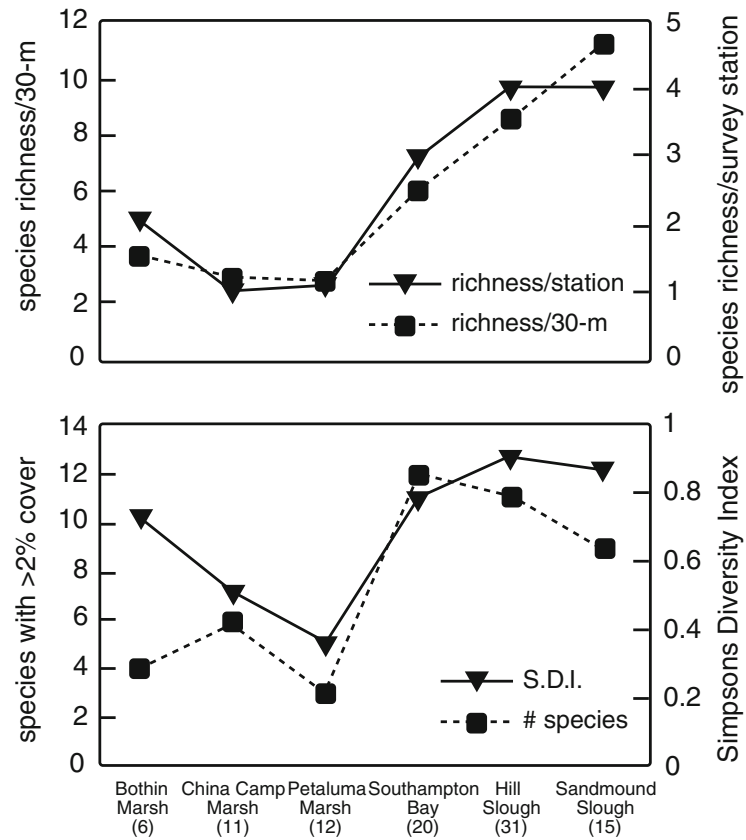

Fig. 4 Measures of plant species a richness and $\mathbf{b}$ evenness over the salinity gradient of the San Francisco Estuary. a Shows median number of species present at each survey station, and median number of species present along 30-m subtransects. b Shows number of species present at greater than $2 \%$ cover and Simpsons diversity index. Values in parentheses below the marsh names indicate total plant species richness

Furthermore, estuary-wide geographic range shifts were noted, including the expansion of salt marsh taxa (Spartina foliosa, Grindelia stricta, Limonium californicum, and Scirpus maritimus) into the brackish portion of the estuary and the recession of saltintolerant taxa (Scirpus acutus, Scirpus californicus) from the saline portion of the estuary. Overall, these patterns are consistent with increases in estuarine salinity, which appears to be increasing due to both watershed-level climate change (Knowles and Cayan 2002) and increases in water diversion for agricultural and municipal use (Stahle et al. 2001).

At Richardson Bay, a low-elevation salt marsh, Spartina foliosa increased significantly in cover. At China Camp, Spartina foliosa declined on the inland edges of tidal channels, while Salicornia virginica expanded modestly. At Petaluma Marsh, Distichlis spicata declined, while Scirpus maritimus and Scirpus americanus increased. At Southampton Bay, Salicornia virginica and Spartina foliosa expanded, while Scirpus californicus and Distichlis spicata declined. At Hill Slough, Scirpus americanus expanded at the expense of Distichlis spicata; furthermore, Scirpus californicus declined. At Sandmound Slough, Typha latifolia, Phragmites australis, and Scirpus californicus declined due to the expansion of more salt-tolerant species such as Scirpus americanus.

The distribution of common marsh plants was mapped onto environmental gradients present in each marsh (Fig. 5). Arrows show ongoing shifts in environmental conditions, including increases in salinity and decreases in elevation relative to tide levels. Overall, these changes in vegetation tend to be indicative of either an increase in sea level (increases in Spartina foliosa, Scirpus americanus; decline in Distichlis spicata), or an increase in salinity (increase in Salicornia virginica, decreases in Spartina foliosa and Scirpus californicus).

Predictions for marsh-specific plant distribution changes for the future were developed using the current ranges for each plant species in each marsh. Potential future changes in marsh plant species distribution (Table 4) will depend on whether sediment accumulation matches the rate of sea level rise. If that is the case, elevation relative to tidal flooding will hold steady; estuarine salinity will increase. If sediment accumulation is outpaced by relative sea level rise, then increased tidal flooding and increased salinity will counteract each other. This is because the highest sediment salinities were found at high elevations for all the profiled wetlands. At low marsh elevations, summer sediment salinity matches water salinity (and thus will increase with water salinity); at high elevations, summer sediment salinity is higher than water salinity due to infrequent flooding and evaporation. Increased flooding of high-elevation marshes will lead to salts being flushed from sediments and apparent sediment salinity declines.

Future changes in geographic species ranges and biodiversity will likewise depend on the marsh elevation response to sea level rise: if sediment accretion keeps pace with sea level rise, the current trend of "salinization" will increase; marsh species diversity will decline in the brackish region of the estuary; if sea level rise outpaces marsh accretion, marsh surfaces will become less saline, and species typically found at low elevations (Scirpus sp., Typha sp., Spartina foliosa) will become more common. In that case, measures of marsh plant species evenness and plot scale diversity would be expected to increase for salt marshes. 

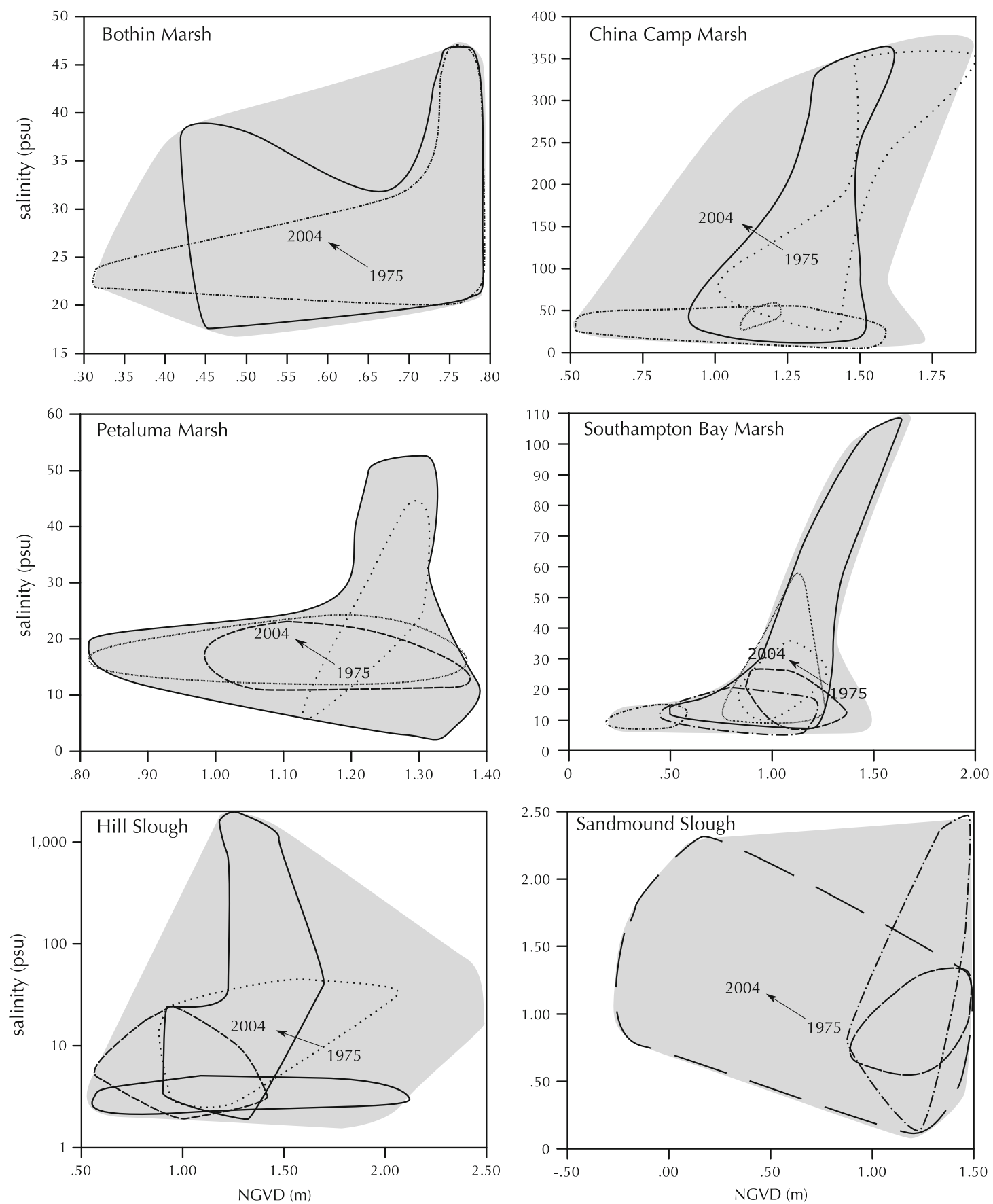

Salicornia virginica Distichlis spicata

Scirpus americanus Typha latifolia

Fig. 5 Environmental envelopes of individual species are denoted by dashed lines. All the combinations of environmental variables found on the marsh are denoted by shading. Arrows show

\section{Spartina foliosa Scirpus maritimus}

Scirpus californicus Phragmites australis

potential shifts in relative elevation and salinity for the last three decades (increasing salinity; decreasing elevation relative to sea level) 
Table 4 Predictions

Scenario 1: Marsh surface accretion keeps up with sea level rise; salinity increases
Scenario 2: Marsh surface accretion does not keep up with sea level rise; relative elevation falls; salinity increases on the low marsh; salinity on the high marsh falls

\begin{tabular}{ll}
\hline Bothin Marsh & $\begin{array}{l}\text { Decline in Spartina foliosa, } \\
\text { Increase in Salicornia virginica }\end{array}$ \\
China Camp & $\begin{array}{l}\text { Increase in Salicornia virginica relative to Scirpus } \\
\text { maritimus and Spartina foliosa, particularly at } \\
\text { higher spots on the marsh }\end{array}$
\end{tabular}

Petaluma Marsh
Increase in Salicornia virginica and Distichlis spicata relative to Scirpus species

Southampton Bay Increase in Salicornia virginica, Distichlis spicata, and Scirpus maritimus and decline in Scirpus californicus and Typha species

Hill Slough

Increase in Salicornia virginica and Distichlis spicata

Sandmound Slough Decrease in Scirpus californicus, increase in Scirpus americanus and other brackish species such as Potentilla anserina
Increase in Spartina foliosa; decrease in Salicornia virginica. Marsh is currently low in elevation so plant replacement should occur quickly

Increase in Spartina foliosa and Scirpus maritimus relative to Distichlis spicata and Salicornia virginica. Marsh is currently at high elevation so plant replacement should not occur soon or at all

Increase in Spartina foliosa, Scirpus maritimus, and Scirpus americanus; decrease in Salicornia virginica and Distichlis spicata

Increase in Spartina foliosa, and Scirpus americanus relative to Distichlis spicata

Decline in Scirpus californicus and Typha species

Increase in Scirpus americanus, and other brackish species common at lower marsh elevations, such as species of Carex, Triglochin, and Typha

Increase in taxa found at low elevations, such as species of Scirpus

\section{Discussion}

Tidal marsh plant distributions

In comparison to typical upland ecosystems, tidal marshes tend to support low floristic diversity with a large portion of endemic species, coupled with harsh environmental gradients. Thus, tidal marshes have long been treated as natural laboratories by ecologists, and many studies have related tidal marsh plant distributions to environmental gradients, such as elevation (Hinde 1954; Traut 2005), hydrology (Sanderson et al. 2000; Zedler et al. 1999), and salinity (Callaway et al. 1990; Culberson 2001). Although the stated goal of this study was primarily to define the distribution of wetland plants along the environmental gradients found in San Francisco Estuary tidal wetlands in order to constrain how future environmental change may affect plant distributions, this study provided a number of key insights in regard to tidal marsh plant distributions that may be applicable to the study of other tidal wetlands.

The results presented here emphasize the role of salinity in structuring tidal marsh plant distributions. First, most marsh plants have fairly broad ranges with respect to elevation and distance to the nearest channel, but have narrow, or relatively characteristic, distributions with respect to sediment salinity. Second, sediment salinity was the best predictor of species presence and absence for five out of seven marsh genera using logistic regression. Diversity at both the plot (Fig. 6) and landscape scale (Fig. 4) varied over the salinity gradient of the estuary, in ways that elevation and channel distance did not. Finally, salinity is the most naturally variable environmental condition. Salinity varies over the course of a season (Josselyn 1983; Zedler 1982), inter-annually due to year-to-year variability in precipitation (Allison 1992; Collins and Foin 1992), due to longer-term climate variability and climate change (May 1999; Byrne et al. 2001; Goman et al. 2008), and due to changes in estuarine morphology (Zedler et al. 1980). Salinity and changes in salinity are responsible for changes in the abundance and distribution of tidal marsh vegetation through time, while indirect gradients focused on by other recent studies are not (e.g., distance metrics, habitat heterogeneity; Morzaria-Luna et al. 2004; Zedler et al. 1999; Sanderson et al. 2000).

Second, the results of this study show that San Francisco Estuary tidal marsh plants were often found 
Fig. 6 Species richness in 1-m diameter circular quadrats. Arrows indicate median species richness at stations more and less saline than the site median. Overall, saline quadrats have lower species richness in brackish marshes. Low elevation quadrats have the same species richness as high elevation quadrats. Quadrats close to tidal channels have higher plotscale diversity in salt marshes, but less species diversity in brackish and fresh marshes sites with sediment salinity $>$ median

sites with sediment salinity $>$ median

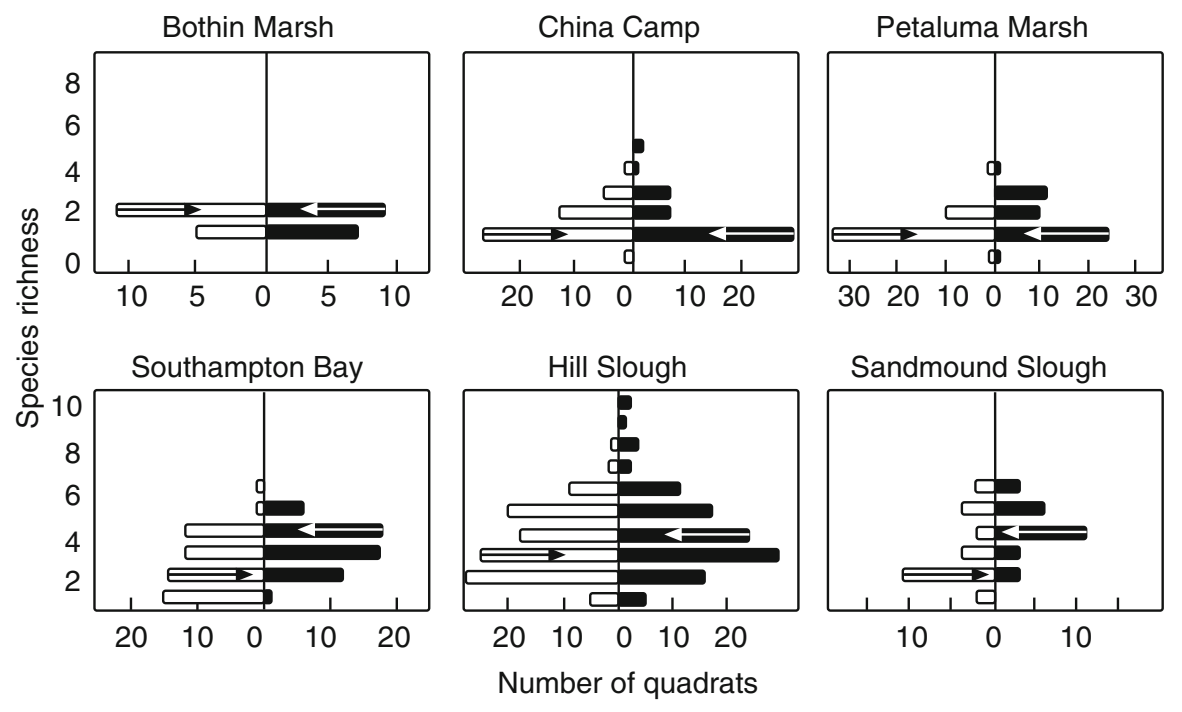

under different environmental conditions in different tidal marshes, and indeed environmental ranges were even found to vary from patch to patch. Plant cover and environmental conditions in nearby stations seem to be highly spatially correlated (see supplementary material)_finding true species ranges involved surveying separate patches and separate wetlands. Studies that seek to relate tidal marsh plant distributions to environmental gradients or heterogeneity should consider the appropriate scale of data collection. Virtually all the recently published studies of tidal marsh vegetation (at least for California) involve transect surveys with survey stations spaced at 2-5 m intervals (Zedler et al. 1999; Traut 2003), which are logistically straight-forward from a fieldwork perspective. However, the high degree of spatial correlation means that any future study should consider spacing survey stations further apart $(\sim 30 \mathrm{~m})$, or sub-sampling closely spaced data to ensure that relationships hold up (the approach taken by this study).

\section{Vegetation change}

This study documents vegetation changes that have occurred in San Francisco Estuary tidal marshes over the last three decades. Distichlis spicata has been nearly replaced in the mesohaline marshes (Petaluma, Southampton Bay, and Rush Ranch) by Scirpus americanus and Scirpus maritimus. Distichlis spicata is generally considered a "high marsh" species; results of this study show that high elevation is the primary predictor of Distichlis spicata presence. The wide-scale replacement of this species suggests some impacts of accelerated sea level rise are already being felt by San Francisco Estuary wetlands. Other species replacements (expansions and declines) are generally salt-tolerant species replacing salt-intolerant species. Furthermore, this study found that at three out of the six marshes, the edge of the vegetated marsh had receded (by as much as many tens of meters at Southampton Bay).

Other evidence of current vegetation change in San Francisco Estuary exists. Studies of recent and fossil pollen in marshland sediment cores have documented a pervasive increase in salt-tolerant vegetation over the past few decades (May 1999; Byrne et al. 2001; Goman et al. 2008). Studies of stable carbon isotopes in marsh sediments also indicate a shift from $\mathrm{C}_{4}$ to $\mathrm{C}_{3}$ marsh species for many locations during recent times (Malamud-Roam and Ingram 2004; Goman et al. 2008). As Distichlis spicata is the only $\mathrm{C}_{4}$ species that grows on the marsh plain, this shift in stable carbon isotopes is likely recording the replacement of Distichlis spicata by other species. Furthermore, anecdotal reports of vegetation in Suisun Marsh indicate ongoing expansion of Scirpus americanus (Culberson 2001), and expansion of both Juncus balticus and Scirpus americanus during wet years (Grewell et al. 2007). In sum, the evidence presented here suggests that 
over past decades, San Francisco Estuary wetland plant distributions have changed in response to both increased salinity and increased water levels.

Future changes in plant distribution hinge on future environmental change. Salinity is expected to increase by 9 psu in the brackish region of the San Francisco Estuary over the next century (Knowles and Cayan 2002), with apparent salinity increases being more observable during wet years. Furthermore, the rate of sea level rise appears to be accelerating, although future rates are uncertain (National Ocean and Atmospheric Administration [NOAA] 2007).

Evidence collected by this study suggests that these two separate forcing mechanisms-increasing salinity and relative sea level rise-may be counteracting each other. Examination of raw environmental data shows that high-marsh salinity is usually found at relatively high elevations on the marsh. At low elevations, and close to tidal channels, sediment salinity remains similar to that of tidal waters; on the high marsh, sediment salinity is concentrated by evaporation and can be many times that of sea water. Hence, although sediment salinity is expected to rise, two future scenarios may be envisioned with respect to high marsh habitat change:

(1) Marsh sediment accretion roughly tracks sea level rise; estuarine salinity increases. Net result is increasing estuarine salinity.

(2) Marsh sediment accretion is outpaced by sea level rise; marsh plains begin to submerge. The net results are an increasing submergence, and through indirect means, a decreasing highmarsh sediment salinity values (although lowmarsh salinity values will increase).

These two future scenarios would result in different predictions of plant distribution changes (Table 4).

If the current trajectory holds, it appears likely that at least some of the marshes around the San Francisco Estuary-in particular wetlands that are currently low in elevation (e.g., Bothin Marsh)—will begin to reflect submergence over the coming decades. However, high-elevation tidal marshes (such as that found at China Camp) are unlikely to experience pervasive vegetation changes. Based on plant abundance along environmental gradients found in this study, sea level rise would have to outpace sediment accretion by nearly $50 \mathrm{~cm}$ for the marsh plain to convert to cordgrass at China Camp. Current trends also suggest that low-marsh species at the extreme limit of their salinity ranges (such as Scirpus californicus at Southampton Bay) will die off and be replaced by more salt-tolerant species. In brackish marshes, this may mean some mudflat de-vegetation, as that occurred during the 1976 drought (Atwater and Hedel 1976; Atwater et al. 1979). Specific predictions of vegetation change are fairly site-specific and depend, at least in part, on the existing marsh plain elevation.

Given the current range of heterogeneity found in San Francisco Estuary tidal marshes with respect to sediment salinity and elevation, it seems implausible that increases in salinity of a few psu, or a sea level increase of $<30 \mathrm{~cm}$ over the next 50 years will result in widespread changes in plant distribution, or complete submergence of tidal marshes. The results of this study generally show fully vegetated tidal marshes, with great natural variability in elevation and salinity, suggesting great resilience to environmental change. However, for many marshes that have deteriorated greatly, in California and elsewhere, there is no simple and easy explanatory factor for marsh deterioration; sediment curtailment (Baumann et al. 1984), altered tidal hydrology (Day et al. 2000; Swanson and Wilson 2008), drought (McKee 2004), pollution impacts (Kolker 2005), and herbivory (Silliman et al. 2005) have all been implicated. Overall, these examples of largely unexplained marsh loss suggest that optimism regarding future marsh resilience should warrant extreme caution.

At least one recent study has suggested that plant diversity in San Francisco Estuary tidal marshes will decline with forecast increases in salinity and sea level (Callaway et al. 2007). The data presented here show that, while indices of biodiversity tend to increase with decreasing salinity, the relationship between diversity and salinity is not straight-forward or linear. First, there are only minor differences in plot- and landscape-scale species richness and measures of species evenness at the three most saline marshes (Bothin Marsh, China Camp, and Petaluma), despite summer maximum water salinity being nearly 10 psu greater at Bothin Marsh than at Petaluma. Second, some of the highest values for species richness and evenness were found at Southampton Bay and Hill Slough, not at Sandmound Slough (the 
freshest site), suggesting that increasing salinity may just move the center of diversity eastward. Lastly, if future environmental change leads to increased tidal flooding, species diversity may possibly increase. The low-elevation salt marsh (Bothin Marsh) has slightly higher indices for species richness and evenness than do China Camp or Petaluma Marsh, which are flooded by less saline tidal waters but are higher in elevation, and so are flooded less frequently and therefore are subject to greater evaporation stress.

Although the specific results and predictions of this study are limited to the wetlands studied, some of the results reported here may also be applicable to other locations. While the complement of marsh plant species found varies from site to site, the expected changes in environment conditions are relatively pervasive. Increased rates of sea level rise are global; wetlands in California and Pacific Northwest are liable to increase in salinity due to factors such as water diversion and snowpack decline.

First, it appears that one of the signals of submergence may be decline in Distichlis spicata, or possibly other solid high-marsh indicator species, long before the marsh plain is invaded by low-marsh species such as Spartina foliosa, or Scirpus sp. Second, the general notion regarding fresh marshes becoming brackish, and brackish marshes becoming saline (per. Callaway et al. 2007), may be an oversimplification. Due to a combination of increased salinity and increasing submergence, some parts of wetlands will become more saline, while other parts will merely become better flushed, no matter what the pre-existing salinity level of the tidal marsh is. Furthermore, the environmental changes described here have been predicted to cause a loss of plot-scale species richness and productivity (Callaway et al. 2007); however, this study found that other indicators of biodiversity (such as species evenness) may increase. This study found higher landscape- and plot-scale biodiversity and the greatest levels of species evenness in the brackish region of the estuary, rather than at nearly fresh salinities in the Sacramento-San Joaquin Delta, indicating that the relationship between salinity and biodiversity is not linear. And finally, changes in productivity will probably hinge on specific species-by-species replacements. The most pervasive vegetation change noted by this study was the replacement of Distichlis spicata by Scirpus americanus - a low-productivity species being replaced by a high-productivity species.
Acknowledgments This study was supported by a National Estuarine Research Reserve Graduate Research Fellowship to E.B.W; grants-in-aid from the Graduate Assembly at UC Berkeley and from the Society of Wetland Scientists; an award to support fieldwork in coastal wetlands from the Garden Club of America. We thank Michael Arribage, Drisanna Watson, Francis Smith, Andy Bliss, Kelly Burkle, Marcy Protteau, and others for assistance in the field during the summers of 2003 and 2004, and Noah Knowles, who provided the salinity data necessary to map surface salinity for San Francisco Bay. This manuscript was substantially improved by constructive comments from Wayne Sousa, Marcy Protteau, and by several anonymous reviewers.

Open Access This article is distributed under the terms of the Creative Commons Attribution Noncommercial License which permits any noncommercial use, distribution, and reproduction in any medium, provided the original author(s) and source are credited.

\section{References}

Adam P (1990) Saltmarsh ecology. University Press, Cambridge

Allison SK (1992) The influence of rainfall variability on the species composition of a northern California salt marsh plant assemblage. Vegetatio 101:145-160

Atwater BF, Hedel CW (1976) Distribution of seed plants with respect to top water levels and water salinity in the natural tidal marshes of the northern San Francisco Bay estuary, California. Open File Report 76-0389. U.S. Geological Survey, Reston

Atwater BF, Conard SG, Dowden JN, Hedel CW, MacDonald RL, Savage W (1979) History, landforms, and vegetation of the estuary's tidal marshes. In: Conomos TJ (ed) San Francisco Bay: the urbanized estuary. Pacific Division of the American Association for the Advancement of Science, San Francisco, pp 347-385

Baumann RH, Day JW, Miller CA (1984) Mississippi Deltaic wetland survival: sedimentation versus coastal submergence. Science 224:1093-1095. doi:10.1126/science.224. 4653.1093

Bower CA, Wilcox LV (1965) Soluble salts. In: Black CA (ed) Methods of soils analysis Part 2. American Society of Agronomy, Madison, pp 933-940

Byrne R, Ingram BL, Starratt S, Malamud-Roam F, Collins J, Conrad M (2001) Carbon-isotope, diatom, and pollen evidence for Late Holocene salinity change in a brackish marsh in the San Francisco Estuary. Quat Res 55:66-76. doi:10.1006/qres.2000.2199

Callaway RM, Jones S, Ferren WR Jr, Parikh A (1990) Ecology of a Mediterranean-climate estuarine wetland at Carpinteria, California: plant distributions and soil salinity in the upper marsh. Can J Bot 68:1139-1146

Callaway JC, Parker VT, Vasey MC, Schile LM (2007) Emerging issues for the restoration of tidal marsh ecosystems in the context of predicted climate change. Madrono 54:234-248. doi:10.3120/0024-9637(2007)5 4[234:EIFTRO]2.0.CO;2 
Chen H, Qualls RG, Blank RR (2005) Effect of soil flooding on photosynthesis, carbohydrate partitioning and nutrient uptake in the invasive exotic Lepidium latifolium. Aquat Bot 82:250-268. doi:10.1016/j.aquabot.2005.02.013

Collins J, Foin TC (1992) Evaluation of the impacts of aqueous salinity on the shoreline vegetation of tidal marshlands in the San Francisco Estuary. In: Schubel JR (ed) Managing freshwater discharge to the San Francisco Bay/San Joaquin Delta Estuary: the scientific basis for an estuarine standard. San Francisco Estuary Project. U.S. Environmental Protection Agency, San Francisco, pp C1-C34

Conomos TJ (1979) Properties and circulation of San Francisco Bay water. In: Conomos TJ (ed) San Francisco Bay: the urbanized estuary. Pacific Division of the American Association for the Advancement of Science, San Francisco, pp 47-84

Conomos TJ, Smith RE, Gartner JW (1985) Environmental setting of San Francisco Bay. Hydrobiologia 129:1-12. doi:10.1007/BF00048684

Culberson SD (2001) The interaction of physical and biological determinants in determining vegetation zonation in tidal marshes of the San Francisco Estuary, California, USA. Dissertation, University of California, Davis, CA

Culberson SD, Foin TC, Collins JN (2004) The role of sedimentation in estuarine marsh development within the San Francisco Estuary, California, USA. J Coast Res 20:970979. doi:10.2112/03-0033.1

Day JW, Rybczyk J, Scarton F, Rismondo A, Are D, Cecconi G (1999) Soil accretionary dynamics, sea-level rise and the survival of wetlands in Venice Lagoon: a field and modeling approach. Estuar Coast Shelf Sci 49:607-628. doi:10.1006/ecss.1999.0522

Day JW, Britsch LD, Hawes SR, Shaffer GP, Britsch LD, Reed DJ, Cahoon D (2000) Pattern and process of land loss in the Mississippi Delta: a spatial and temporal analysis of wetland habitat change. Estuaries 23:425-438. doi:10.2307/1353136

Donnelly JP, Bertness MD (2001) Rapid shoreward encroachment of salt marsh cordgrass in response to accelerated sea-level rise. Proc Natl Acad Sci USA 98:14218-14223. doi:10.1073/pnas.251209298

Donnelly JP, Webb T III, Prell WL (1999) The influence of accelerated sea-level rise, human modification and storms on a New England salt marsh. Curr Top Wetl Biogeochem 3:152-160

Goman M, Malamud-Roam F, Ingram BL (2008) Holocene environmental history and evolution of a tidal salt marsh in San Francisco Bay, California. J Coast Res 24:11261137. doi:10.2112/08A-0005.1

Grewell BJ, Callaway JC, Ferren WR (2007) Estuarine wetlands. In: Barbour MG, Keeler-Wolf T, Schoenherr AA (eds) Terrestrial vegetation of California, 3rd edn. University of California Press, Berkeley, pp 124-154

Hartig EK, Gornitz V, Kolker A, Mushacke F, Fallon D (2002) Anthropogenic and climate-change impacts on salt marshes of Jamaica Bay, New York City. Wetlands 22:71-89. doi: 10.1672/0277-5212(2002)022[0071:AACCIO]2.0.CO;2

Hickman JC (1993) The Jepson manual: higher plants of California. University of California Press, Berkeley

Hinde HP (1954) The vertical distribution of salt marsh phanerogams in relation to tide levels. Ecol Monogr 24:209-225. doi:10.2307/1948621
Josselyn M (1983) The ecology of San Francisco Bay tidal marshes: a community profile. U.S. Fish and Wildlife Service, Division of Biological Services, Washington, DC

Knowles N (2000) Modeling the Hydroclimate of the San Francisco Bay-Delta Estuary and Watershed. Dissertation, Scripps Institution of Oceanography. La Jolla, CA, University of California, San Diego, CA

Knowles N (2002) Natural and management influences on freshwater inflows and salinity in the San Francisco Estuary at monthly to interannual scales. Water Resour Res 38:1289. doi:10.1029/2001WR000360

Knowles N, Cayan DR (2002) Potential effects of global warming on the Sacramento/San Joaquin watershed and the San Francisco Estuary. Geophys Res Lett 29:1891. doi:10.1029/2001GL014339

Kolker A (2005) The impacts of climate variability and anthropogenic activities on salt marsh accretion and loss on Long Island. Dissertation, Stony Brook University, Stony Brook, New York

Malamud-Roam F, Ingram BL (2004) Late Holocene $\delta^{13} \mathrm{C}$ and pollen records of paleosalinity from tidal marshes in the San Francisco Bay Estuary, California. Quat Res 62:134-145

May M (1999) Vegetation and salinity changes over the last 2000 years at two wetland islands in the northern San Francisco Estuary, California. Thesis. University of California, Berkeley, CA

McKee KL (2004) Acute salt marsh dieback in the Mississippi River deltaic plain: a drought-induced phenomenon? Glob Ecol Biogeogr 13:65-73. doi:10.1111/j.1466-882X.2004. 00075.x

Mitsch WJ, Gosselink JG (2000) Wetlands, 3rd edn. Wiley, New York

Morzaria-Luna H, Callaway JC, Sullivan G, Zedler JB (2004) Relationship between topographic heterogeneity and vegetation patterns in a Californian salt marsh. J Veg Sci 15:523-530

National Ocean and Atmospheric Administration [NOAA] (2007) Online water level records. Available from http://coops.noaa.gov. Accessed 17 Dec 2007

Odum EP (1980) The status of three ecosystem level hypotheses regarding salt marsh estuaries: tidal subsidy, outwelling and detritus-based food chains. In: Kennedy VS (ed) Estuarine perspectives. Plenum, New York, pp 485-495

Orr M, Crooks S, Williams PB (2003) Will restored tidal marshes be sustainable? San Franc Estuary Watershed Sci 1:5

Orson RA, Howes BL (1992) Salt marsh development studies at Waquoit Bay, Massachusetts: influence of geomorphology on long-term plant community structure. Estuar Coast Shelf Sci 35:453-471. doi:10.1016/S0272-7714(05)80025-3

Peterson D, Cayan D, DiLeo J, Noble M, Dettinger M (1995) The role of climate in estuarine variability. Am Sci 83:58-67

Pyke CB (1972) Some meteorological aspects of the seasonal distribution of precipitation in the Western United States and Baja, California. Dissertation, University of California, Berkeley, CA

San Francisco Estuary Project [SFEP] (2008) The San Francisco Estuary Project. Available from http://sfep.abag. ca.gov/. Accessed 20 Dec 2008

Sanderson EW, Ustin SL, Foin TC (2000) The influence of tidal channels on the distribution of salt marsh plant species in Petaluma Marsh, CA, USA. Plant Ecol 146:2941. doi:10.1023/A:1009882110988 
Silliman BR, van de Koppel J, Bertness MD, Stanton LE, Mendelssohn IA (2005) Drought, snails, and large-scale die-off of Southern U.S. salt marshes. Science 310:18031806. doi:10.1126/science. 1118229

Stahle DW, Therrell MD, Cleaveland MK, Cayan DR, Dettinger MD, Knowles N (2001) San Francisco Bay salinity reconstruction. In: International tree-ring data bank. IGBP PAGES/World Data Center for Paleoclimatology. Data Contribution Series \#2001-031. NOAA/NGDC Paleoclimatology Program, Boulder. Available via ftp://ftp.ncdc. noaa.gov/pub/data/paleo/treering/reconstructions/california/ sfbay_salinity.txt Accessed 15 Mar 2007

Swanson RL, Wilson RE (2008) Increased tidal ranges coinciding with Jamaica Bay development contribute to marsh flooding. J Coast Res 24:1565-1569. doi:10.2112/07-0907.1

Traut BH (2003) The high salt marsh ecotone: a study of its structure and function and the influence of grazing and nitrogen addition on its nutrient dynamics. Dissertation. University of California, Davis, CA

Traut BH (2005) Effects of nitrogen addition and salt grass (Distichlis spicata) upon high salt marsh vegetation in northern California, USA. Estuaries Coasts 28:286-295. doi:10.1007/BF02732862

Uncles RJ, Peterson DH (1995) A computer model of longterm salinity in San Francisco Bay: sensitivity to mixing and inflows. Environ Int 21:647-656. doi:10.1016/01604120(95)00075-V

Uncles RJ, Peterson DH (1996) The long-term salinity field in San Francisco Bay. Cont Shelf Res 16:2005-2039

U.S. Fish and Wildlife Service (1987) Birds of San Francisco Bay and San Pablo Bay National Wildlife Refuges.
Northern Prairie Wildlife Research Center, Jamestown, North Dakota

U.S. Salinity Laboratory (1954) Handbook 60: diagnosis and improvement of saline and alkaline soils. U.S. Department of Agriculture, Washington, DC

van der Wal D, Pye K (2004) Patterns, rates and possible causes of saltmarsh erosion in the Greater Thames area (UK). Geomorphology 61:373-391. doi:10.1016/j.geomorph. 2004.02.005

Van Dyke E, Wasson K (2005) Historical ecology of a central California estuary: 150 years of habitat change. Estuaries 28:173-189. doi:10.1007/BF02732853

Warren RS, Niering WA (1993) Vegetation change on a northeast tidal marsh: interaction of sea-level rise and marsh accretion. Ecology 74:96-103. doi:10.2307/1939504

Watson EB (2006) Environmental change in San Francisco Estuary tidal marshes. Dissertation, University of California, Berkeley, CA

Young JA, Turner CE, James LF (1995) Perennial pepperweed. Rangelands 17:121-123

Zedler JB (1982) The ecology of southern California coastal salt marshes: a community profile. United States Department of Interior, Washington, DC

Zedler JB, Winfield T, Williams P (1980) Salt marsh productivity with natural and altered tidal circulation. Oecologia 44:236-240. doi:10.1007/BF00572685

Zedler JB, Callaway JC, Desmond JS, Vivian-Smith G, Williams GD, Sullivan G, Brewster AE, Bradshaw BK (1999) Californian salt-marsh vegetation: an improved model of spatial pattern. Ecosystems (N Y, Print) 2:19-35. doi: $10.1007 / \mathrm{s} 100219900055$ 